\title{
Factors Affecting the Online Shopping Behavior of Consumers among Uum Community
}

\author{
Rawiyah Abd Hamid* \\ School of Business Management, Universiti Utara Malaysia, Malaysia \\ *Corresponding Author: Rawiyah Abd Hamid, School of Business Management, Universiti Utara \\ Malaysia, Malaysia
}

\begin{abstract}
The purpose of this study is to examine the relationship between attitude, subjective norm and perceived risks towards the online shopping among the consumer in Malaysia. Community of Universiti Utara Malaysia (UUM) were chosen as sample in this study. This survey used 377 questionaire which were distributed to UUM community by google using google form. Pearson correlation and Cronbach's Alpha were adopted to analyze all the data. The finding indicated that all the independent variables which are attitude, subjective norms and perceived risks has certain degree of relationship with online shopping behavior. The result indicated that subjective norms $(r=0.568)$ had the strongest significant positive relationship with online shopping behavior compared attitude $(r=0.440)$ and perceived risks $(r=0.516)$. The finding suggested that subjective norms can be an important factor that influence online shopping behavior. Consumer will most likely be influenced by idea and suggestions of their close family and friends when they make online purchase.
\end{abstract}

Key words: Attitude, Subjective Norms, Perceived Risks, Online Shopping Behavior

\section{INTRODUCTION}

The growth of internet technology has found to have strong impact on global business. The internet created new environment of e-commerce and has provided opportunities to connect busing through internet across worldwide, new markets are developed to improve the social benefits and produce greater profits by accessing the internet (Katawetawaraks\& Wang (2018). The usage of internet has increased due to it significant tools of fast information delivery to the users also providing more choices of browsing in a shortest possible time. Today, internet is use for several purposes including online shopping is populace. Online shopping is also one of the components of e-commerce which is defined as the using of internet and other networks to purchase, sell, transport or trade data, goods or services (Turban et al., 2017). The online shopping open new window for the business where is known business-to-consumer (B2C) where individual benefits using internet technology to buy and sell products electronically, besides provide and interface from business directly to the consumers (Kirthy\&Jabez, 2018).

Previous study the survey revealed that $67.0 \%$ Malaysian plan to purchase online air tickets which is the third highest online air tickets buying, 64.0\% reserved hotel rooms through internet and 58.0\% Malaysian would purchase online event tickets (Ahmad et al., 2016). Where, Malaysia is ranked 3rd for online travel tickets, second for hotel room reservation the other products online selling found lower such as electronics, grocery etc. Although, the rapid growth of online shopping market is the optimistic for the future growth, but negative aspects arose in conventional shopping method. Lack of visual contact or physical existence of the product the trust related factor among consumer is highly dominated in online shopping and discourages method of online shopping (Chowdhury \& Ahmad, 2011 and Lim et al., 2016).

According to Katawetawaraks\& Wang (2018), online shopping model is strongly based on the consumer trust since security and privacy of the customer become an imperative, where privacy security has become the biggest hinder for the development of online shopping in the big data era. The consumer behavior is critical to decode during transaction because of consumer contribution is not exist. According to the study internet usage and online shopping, it is reported that $47 \%$ 
respondents shop online frequently, 30\% respondents shop online seldom while $23 \%$ respondents never tried to shop online.

\section{LITERATURE REVIEW}

\subsection{Attitude and Consumer Behavior towards Online Shopping in Malaysia.}

Since the mid-1970s, the study of consumer's attitudes has been associated with consumer purchasing behavior research. According to the model of attitude change and behavior (Chew \&Adis, 2018; Fishbein \&Aizen, 1975). Consumer attitudes are affected by intention. When this intention is applied to online shopping behavior, the research can examine the outcome of the purchase transaction. As a rule, the more favorable the attitude and subjective norm with respect to engaging in the behavior, and the greater the perceived control, the more likely it is that a person will form an intention to perform the behavior in question. Finally, intentions are expected to lead to performance of the behavior to the extent that people are in fact capable to the extent that they have actual control over the behavior (Aizen, 2005). Attitude is a multi-dimensional construct. One such dimension is the acceptance of the Internet as a shopping channel (Jahng, Jain \& Ramamurthy, 2017). Previous research has revealed attitude towards online shopping is a significant predictor of making online purchases. Trust and perceived benefits are key predictors of consumer attitudes toward online shopping, according to the results. Further, the authors also found that higher levels of perceived web quality lead to higher levels of trust in an online shopping web site and purchasing behavior (Debei, 2014). Online shopping experiences could affect the attitude of online shopper to purchase through the internet (Khalifa \& Venessa, 2007). Consumer attitudes are a composite of a consumer's beliefs, feelings about, and behavioral intentions toward some object within the context of marketing, usually a brand or retail store. These components are viewed together since they are highly interdependent and together represent forces that influence how the consumer will react to the object. Thus, it is hypothesized that:

H1: There is a significant relationship between attitude and consumer behavior towards online shopping in Malaysia.

\subsection{Subjective Norms and Consumer Behavior towards Online Shopping in Malaysia.}

In order to be successful retailers must understand consumers' purchasing behaviors. This is particularly true for online retailers. A comprehensive understanding must be made of the website's design and support in order to match its consumers' information gathering and purchasing behaviors. The visual stimuli and communication through text and sound can positively or negatively affect consumers' online desires and actions (Tantawi et al, 2015). The Theory of Reasoned Action (TRA) (Azjen\& Fishbein, 1980; Huang, et. al., 2017) has successfully been used to explain human behavior. The theory proposes that human behavior is preceded by intentions, which are formed based on consumers' attitude toward the behavior and on perceived subjective norms. Attitude reflects the individual's favorable or unfavorable feeling towards performing a behavior. Subjective norms capture the consumers' perceptions of the influence of significant others,such as family, peers, authority figures, and media. It is related to intention because people often act based on their perception of what others think they should be doing. Subjective norms tend to be more influential during early stages of innovation implementation when users have limited direct experience from which to develop attitudes (Taylor \& Todd, 1995; Altawallbeh et al, 2015). It is during this stage of attitudinal development that online retailers can influence shoppers' propensity for purchasing behaviors (Yu \& Wu, 2007; Küster et al, 2016). Therefore, it can be hypothesized that:

$\mathrm{H} 2$ : There is a significant relationship between subjective norms and consumer behavior towards online shopping in Malaysia.

\subsection{Perceived Risks and Consumer Behavior towards Online Shopping in Malaysia.}

Perceived risk refers to the nature and amount of risk perceived by a consumer in contemplating a purchase decision (Ariff et al., 2014; Cox \& Rich, 1964). Before purchasing a product, a consumer considers the various risks associated with the purchase. The different types of risks are referred to as perceived or anticipated risks. Research suggests that consumers generally prefer to use electronic commerce for purchasing products that do not require physical inspection (Shanthi \&Kannaiah,2015). The higher the perceived experience risk, the consumer may shift to brick-and-mortar retailer for the purchase of the product. Hence, the higher the perceived risk, the lower the propensity for online shopping (Lubis et al., 2017\&Ariff et al., 2014). Risks perceived or real, exist due to technology 
failure. The most frequently cited risks associated with online shopping include financial risk, product risk, convenience, and non-delivery risk. The level of uncertainty surrounding the online purchasing process influences consumers' perceptions regarding the perceived risks. Thus, it is hypothesized that:

H3: There is a significant relationship between perceived risks and consumer behavior towards online shopping in Malaysia.

\section{CONCEPTUAL FRAMEWORK AND THEORETICAL BACKGROUND}

The present theoretical framework is formulated after reviewing related literatures on the factors affecting the online shopping behavior of consumers among UUM community. The dependent variable (DV) is "Consumer Behavior towards Online Shopping" which relies on independent variables (IV) which consists of three factors that influence the consumer behavior (DV) namely attitude, subjective norms and perceived risks. The research framework of this research is shown in the Figure 1 which shows the variables that need to be examined according to the research objectives, research questions and research hypotheses.

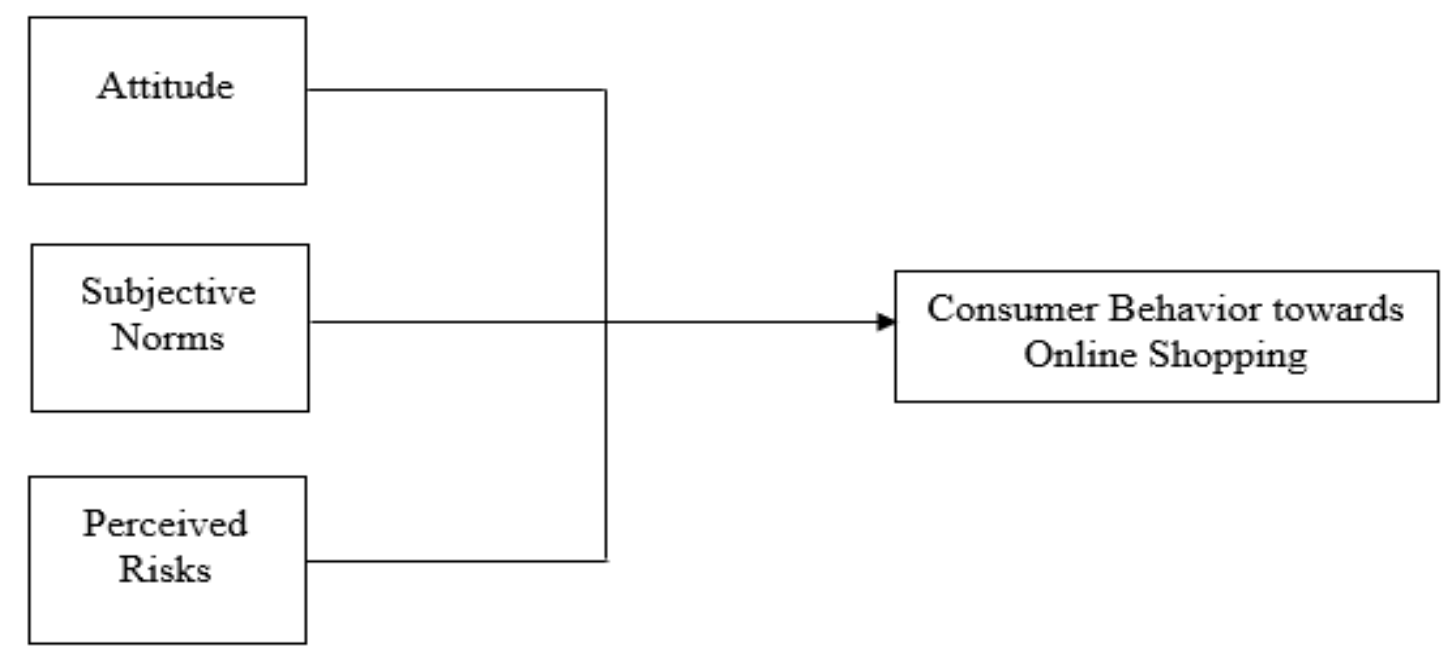

\section{Independent Variables}

\section{Dependent Variable}

Figure1. Research Framework

\section{RESEARCH METHODOLOGY}

\subsection{Research Design}

This study has employed quantitative approach to test the hypothesis in the research framework (Figure 1). The study was conducted explanatory research used to determine the choice research design. It is essential to identify the factors relates with the variables of interest. Hypothesis testing is conducted under explanatory research in order the relationship between dependent variable and independent variable. In this study, correlation study is carried out to test the relationship between consumer behavior towards online shopping and attitude, subjective norms and perceived risks. The intervention level for this study is low since there is no manipulation on independent variables. This is because quantitative study is conducted in a nature environment and minimal interference. Study setting can be either be contrived and non-contrived. Contrived setting means research is done in artificial environment while non-contrived setting means research in done in the natural environment whether works proceed normally (Khairy, 2010). For the study, non-contrived setting is conducted. A field study is used to avoid the study is being manipulated and controlled by researcher. Questionnaires were distributed in order to collect the data. The collected data are then analyzed by SPSS and the results are then generalized to the entire population

\subsection{Sample, Population, Unit of Analysis}

In this study, UUM community is treated as individual under unit of analysis. The study focuses on how the consumer behavior on individuals towards online shopping, then researcher is interested in individual UUM community and would like to identify the factors influencing their behavior towards 
online shopping. In this study, survey research is being used to gathering data from people in order to measure their consumer behavior towards online shopping is influenced by attitude, subjective norms and perceived risks. Time horizon can be considered either cross sectional or longitudinal studies. Cross sectional research is a snapshot of constructs at a single point in time. Data collection is done at one time only. On the other hand, longitudinal research is a snapshot of constructs at multiple points in time. For the study, cross sectional research design is carried out as researcher collect data and information from UUM community at one point in time. The advantage of convenience sampling is the data collection can be done in the short period of time and to avoid the wasting of time. Through this research, researcher will use the Krejcie and Morgan Table in determining the number of respondents needed in this study. From the table, if the population estimated is 20000 community, therefore the number of respondents needed is 377 respondents.

\subsection{Measurement of Variables}

In this research, researcher decided to use the non-probability sampling techniques because a sampling framework is not available. Based on this technique, researcher have been used convenience sampling techniques. Convenience sampling is the technique where is first available primary data source will be used for the research without additional requirements and it involves the participants such as relative, friends and shoppers. In this study researcher will involves the participants of UUM community. In this study, all the variables are tested through set of questionnaires. Zikmund, Carr\& Griffin (2012) had implied that the questionnaire can address the research question must be relevant to the extent of all information that are collected. The questionnaires also must be precise, where all the information must be reliable and valid. The questionnaire administration method used in this study is through online google form which attach the link to the questionnaire. The questions used a five points Likert Scale method where the respondents have to respond to the questions according to their understanding towards the questions and the respondents usually read and answer the questions on their own that best represent their opinion or attitude on a particular issue. According to Zikmund (2012) Likert scale is a measurement of approach and manner that have been devised to empower the respondents to give rate based on their assent on how neither extremely nor strongly they agree or disagree with carefully constructed statements.

\subsection{Data Collection and Analysis}

Inthis study, questionnaire is divided into four sections which included demographic information in Section A and have 24 questions that are related to the independent variables and dependent variable which captured questions related to attitude, subjective norms and perceived risks towards consumer behavior on online shopping in Section B to Section D which to ensure the questions to be understood accurately by the respondents. Besides, the questionnaire will be conducted in simple English to ensure understanding of the question by the respondents.

\section{DATA ANALYSiS}

\subsection{Demographic Profiles}

Demographic analysis is used to analyze the demographic background of the respondent and this can help researcher to gain more accurate data and information. Through the demographic analysis, researcher can know the respondent's gender, age, race, highest level of certificate, marital status and income. In this study, researcher have collected 377 respondents in UUM. Total of 377 respondents have responded to this questionnaire. The sample chosen for this study is 300 UUM community. The response rate of this project s 100\% where there are 300 of the questionnaires have been given out and 377 respondents have responded and answered to the questionnaire and there are no missing for the respondents.

\subsection{Hypothesis Testing Results}

As Hypothesis testing is the techniques and practice to test a theory by contrasting it with the hypothesis to make statistical decision using an experimental data (Sekaran\& Bougie, 2016). A Pearson Correlation was computed in this study to assess the relationship between independent variables (attitude, subjective norms and perceived risks) and dependent variable (online shopping behavior). The Table1 below shows the Pearson Correlation scale that refer to determine the level of relationship between variables. In this study, Pearson Correlation was using the correlation analysis to test those variables' relationship. 
Table1. Pearson Correlation Scale

\begin{tabular}{|l|l|l|l|l|}
\hline Correlations & Attitude & $\begin{array}{l}\text { Subjective } \\
\text { Norms }\end{array}$ & Perceived Risks & Online Shopping Behavior \\
\hline Attitude & 1 & $.428^{* *}$ & $.175^{* *}$ & $.440^{* *}$ \\
\hline Subjective Norms & $.428^{* *}$ & 1 & $.326^{* *}$ & $.568^{* *}$ \\
\hline Perceived Risks & $.175^{* *}$ & $.326^{* *}$ & 1 & $.516^{* *}$ \\
\hline Online Shopping Behavior & $.440^{* *}$ & $.568^{* *}$ & $.516^{* *}$ & 1 \\
\hline$* *$ Correlation is significant at the 0.01 level (2-tailed). \\
\hline
\end{tabular}

Findings from the table above shows that there is positive relationship between the three variables. A significant level occurs when $\mathrm{p}<0.05$. Therefore, attitude, subjective norms and perceived risks has a significant relationship with the online shopping behavior because $p=0.000$. For the significant relationship between attitude and online shopping behavior recorded the value is $\left(\mathrm{r}^{2}=0.440, \mathrm{p}=0.000\right)$. While for the significant relationship between the subjective norms and online shopping behavior demonstrated the value, which is $\left(\mathrm{r}^{2}=0.568, \mathrm{p}=0.000\right)$. Finally, the result of correlation shows the significant relationship between the perceived risks and the online shopping behavior with the value of $\left(\mathrm{r}^{2}=0.516, \mathrm{p}=0.000\right)$. Therefore, all hypothesis as stated above are supported. There is a greatest positive relationship $\left(\mathrm{r}^{2}=0.568\right)$ between subjective norms and online shopping behavior which indicates that when the level of subjective norms is high, the online shopping behavior of UUM community will also increase. It shows a strong relationship ( $>0.50$ ). While attitude and online shopping behavior shows the weakest relationship $\left(\mathrm{r}^{2}=0.440\right)$ between each other in this study and it is considered as moderate relationship which is lying on the range of 0.30 to 0.49 .

\section{CONCLUSION AND DiscuSSION}

Based on the research findings of this study empirically tested the affecting the online shopping behavior of consumer among UUM community, researcher can conclude that attitude, subjective norms and perceived risks factors will affect the online shopping behavior among UUM community. To summarize, this research is conducted essentially to study whether the important factors which related to online shopping behavior among UUM community. The sample used are UUM community which are chosen randomly by different gender, age, race, highest level of education, marital status and income. First and foremost, researcher discover that there are some factors which affect the online shopping behavior of UUM community which are attitude, subjective norms and perceived risks. These factors are directly affecting the online shopping behaviors among UUM community. Pearson correlation has been executed to determine the relationship between dependent variable and independent variables of this study. In hypothesis one testing relationship between attitude and online shopping behavior, the result shows that all the three variables have significant. Therefore, attitude, subjective norms and perceived risks shows significant positive relationship with online shopping behavior.

\section{IMPLICATION}

The study has extracted 3 factors that affect the online shopping behavior among UUM community which are attitude, subjective norms and perceived risks. Since the online shopping behavior can be vary over time due to some reasons, therefore researcher should conduct the survey to the participants twice, once at the beginning of the semester and once again at the end of the semester to see the changes in the online shopping behavior among UUM community to ensure the accuracy and the reliability of the result. From the conclusion above, several research applications are resulted in this study.

First, an attitude of a person will affect the online shopping behavior. This is because the moment a person makes a purchase on the online shopping, there is some criteria that the person has in purchasing the product. For example, the price range, the material, the specifications and so on. These criteria will act as the barrier for one product being sold out. Therefore, seller should always make the market research to determine the behavior of the consumers when they want to launch a new product. Some of the important criteria that they should always take note are price and the quality of the material. In short, attitude of an individual will impact its online shopping behavior.

Secondly, the result of the study has proven that subjective norms will impact the online shopping behavior of the consumers too. This is because mostly the decision on the product on the online shopping will be influenced by people surrounding such as family and friends when the individual has 
dilemma in choosing the things that the person want to purchase. If the people surrounding have the bad experience on the product, this will directly cause the mindset of the purchaser influenced and subsequently they will not purchase the product too. From here, researcher can know that subjective norms will affect the online shopping behavior of an individual.

Third is that perceived risks will also impact the online shopping behavior of consumers. This is because there are the underlying risks appeared where the transaction on the online business is done in virtual where researcher cannot see the real face of the seller like the normal face-to-face transaction. Researcher can just only obtain the information of the seller merely through the webpage and the reliability of the webpage is questionable. Moreover, there are many cases reported regarding the scam on the online business nowadays and this will cause more people will be alerted when they purchased their items online. Therefore, this shows that perceived risks will directly impact the online shopping behavior among UUM community.

\section{REFERENCES}

[1] Ajzen, I. \& Fishbein, M. (1980). Understanding attitudes and predicting social behavior. EnglewoodCliffs, NJ: Prentice-Hall.

[2] Ajzen, I. (1991). The theory of planned behavior. Organizational. Behavior and Human Decision Processes, 50, 179-211.

[3] Ajzen, I. (2005). Attitudes, personality, and behavior (2nd ed.). Maidenhead, UK: Open University Press.

[4] Ajzen, I. (2012). The theory of planned behavior. In: Lange, P.A.M., Kruglanski, A.W., and Higgins, E.T.

[5] (Eds.), Handbook of theories of social psychology 1, 438-459. London, UK: Sage.

[6] Ariff, M. S. M., Sylvester, M., Zakuan, N., Ismail, K., \& Ali, K. M. (2014). Consumer perceived risk, attitude and online shopping behaviour; Empirical evidence from Malaysia. Paper presented at the IOP Conference Series: Materials Science and Engineering.

[7] Ahmad, Kartini\&Anindita, (2016). Developing Conceptual Model for Online Shopping Attitude in Indonesia: Based on the Diffusion of Innovations Theory. International Journal of Economics, Commerce and Management, 22.

[8] Altawallbeh, M \& Soon, F \& Thiam, W \&Alshourah, S. (2015). Mediating Role of Attitude, Subjective

[9] Norm And Perceived Behavioural Control In The Relationships Between Their Respective Salient Beliefs And Behavioural Intention To Adopt E-Learning Among Instructors In Jordanian Universities Journal of Education and Practice. 6 (11).

[10] Chew, B. E., \&Adis, A, A., (2018); A Study on Malaysian Consumers' Attitude and Behavioral Intention Towards Print Advertising. International Journal of Marketing Studies. 10(2)

[11] Chowdhury, M. S. \& Ahmad, N. (2011). Factor Affecting Consumer Perticipation in Online In Malaysia: The case of University Students. European Journal of Business and Economics. 5 (1)

[12] Cox, D.F., and Rich, S.U. 1964. Perceived Risk and Consumer Decision Making - The Case of Telephone Shopping. Journal of Marketing Research, 1: 32-39

[13] Debei, M. M. Al. (2014). The quality and acceptance of websites: an empirical investigation in the context of higher education. International Journal of Business Information Systems, 15(2), 170.

[14] Fishbein, M., \&Ajzen, I. (1975). Belief, Attitude, Intention, and Behavior: An Introduction to Theory and Research. Reading, MA: Addison-Wesley.

[15] Fishbein, M., andAjzen, I. (2010). Predicting and changing behavior: The reasoned action approach. New York: Psychology Press.

[16] Huang, K., Yeomans, M., Brooks, A. W., Minson, J., and Gino, F. (2017). It Doesn't Hurt to Ask: Question- Asking Increases Liking. Journal of Personality and Social Psychology 2017 American Psychological Association. Harvard University .113 (3) 430 - 452

[17] Jahng, J., Jain, H., \& Ramamurthy, K., (2017). Effects of interaction richness on consumer attitudes and behavioral intentions in e-commerce: some experimental results European Journal of Information Systems, 16 (3) 254-269.

[18] Katawetawaraks, C., \& Wang, C. L., (2018), Online Shopper Behavior: Influences of Online Shopping

[19] Decision. Asian Journal of Business Research, 1 (2)

[20] Khairy, (2010). Research design - Study Setting Contrived and Noncontrived. D.O.I: December, 2019 https://www.coursehero.com/file/7829595/research-design/

[21] Khalifa, M. \& Vanessa, L. (2007). Online consumer retention: Contingent effects of online shopping habit and online shopping experience. European Journal of Information System. 16 
[22] Kirthy, M. S., and Jabez, R (2018). New Trends in Business Management. Hyderabad: Zenon Academic Publishing.

[23] Küster, Vila \& Canales, (2016). How does the online service level influence consumers' purchase intentions before a transaction? A formative approach. European Journal of Management European Journal of Management, 10.

[24] Lim, Y. J., Osman, A., Salahuddin S, N., Romle, A, R., \&Abdullaj, S. (2016). Factors Influencing Online Shopping Behavior: The Mediating Role of Purchase Intention. Procedia Economics and Finance 35

[25] Lubis, A.N., Lumbanraja, P., Lubis, R.R. \&Hasibuan, B.K. (2017). A study of service quality, corporate

[26] social responsibility, image hospital and hospital value creation in Medan. European Research Studies Journal, 20(4), 125-133.

[27] Sekaran, U. Bougie, R. (2016). Research Methods for Business: A Skill Building Approach (7th edition). New York: John and Sons Publication.

[28] Shanthi, R. \&Kannaiah, D. (2015). Consumers' perception on online shopping. Journal of Marketing and Consumer Research, 13, 14-20.

[29] Tantawi, Negm\&Passent, (2015). Investigating the Impact of Visual Design on Consumers' Perceptions towards Advertising. International Journal of Scientific and Research Publications, 9.

[30] Taylor,S., \&Todd, P.,A. (1995). Understanding Information Technology Usage: A Test of Competing

[31] Models. Information Systems Research. 6(2) 144-176

[32] Yu, T., \& Wu, G, (2007), "Determinants of internet shopping behavior: An application of reasoned behavior theory", International Journal of Management, 24(4)744-762

[33] Zikmund, W. G., Carr, J. C., and Griffin, M. (2012). Business Research Methods. New York: Cengage Publication.

[34] Zikmund,W.G. (2012). Business Research Methods (9th ed.). United States of America, NY: Erin Joyner.

\section{AUTHOR'S BIOGRAPHY}

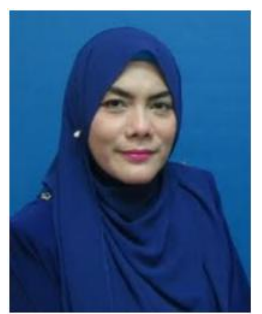

Dr. Rawiyah Abd Hamid, is currently a Senior Lecturer at School of Business Management (SBM), College of Business (COB), Universiti Utara Malaysia (UUM). She successfully completed her PhDin Entrepreneurship from Universiti Tun Hussein Onn Malaysia (UTHM). Her area of expertise in Entrepreneurship, Business Management;and TechnicalVocational Education in Management

Citation: Rawiyah Abd Hamid. "Factors Affecting the Online Shopping Behavior of Consumers among Uum Community" International Journal of Humanities Social Sciences and Education (IJHSSE), vol 7, no. 6, 2020, pp. 123-129. doi: http://dx.doi.org/10.20431/2349-0381.0706014.

Copyright: (C) 2020 Authors. This is an open-access article distributed under the terms of the Creative Commons Attribution License, which permits unrestricted use, distribution, and reproduction in any medium, provided the original author and source are credited. 